\title{
Assessing the influence of subcultures and liquid medium during somatic embryogenesis and plant regeneration in oil palm (Elaeis guineensis Jacq.)
}

\author{
T. R Monteiro, E. O Freitas, G. F Nogueira \& J. E Scherwinski-Pereira
}

To cite this article: T. R Monteiro, E. O Freitas, G. F Nogueira \& J. E Scherwinski-Pereira (2018) Assessing the influence of subcultures and liquid medium during somatic embryogenesis and plant regeneration in oil palm (Elaeis guineensis Jacq.), The Journal of Horticultural Science and Biotechnology, 93:2, 196-203, DOI: 10.1080/14620316.2017.1360156

To link to this article: https://doi.org/10.1080/14620316.2017.1360156

\section{曲 Published online: 14 Aug 2017.}

\section{Submit your article to this journal ¿}

Џ Article views: 38

View Crossmark data ¿ 


\title{
Assessing the influence of subcultures and liquid medium during somatic embryogenesis and plant regeneration in oil palm (Elaeis guineensis Jacq.)
}

\author{
T. R Monteiro ${ }^{a}$, E. O Freitas ${ }^{b}$, G. F Nogueirac and J. E Scherwinski-Pereira $\mathbb{1}^{d}$
}

anstituto de Biologia, Departamento de Botânica, PPGBot, Universidade de Brasília, Brasília, DF, Brazil; 'bFaculdade de Tecnologia, Departamento de Engenharia Florestal, PG/EFL, Universidade de Brasília, Brasília, DF, Brazil; 'Projeto Capes/Embrapa, Embrapa Recursos

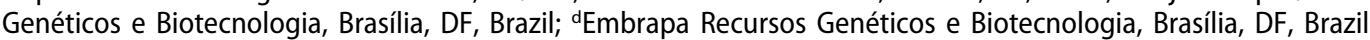

\section{ABSTRACT}

The current analysis describes an improved protocol for somatic embryogenesis and plant regeneration in oil palm (Elaeis guineensis) through liquid medium, and assesses the influence of successive subcultures during induction of calluses in three Brazilian oil palm varieties. Calluses were induced in a Murashige and Skoog (MS) medium with 450 Picloram, $0.5 \mathrm{~g} \mathrm{~L}^{-1}$ glutamine, $2.5 \mathrm{~g} \mathrm{~L}^{-1}$ activated charcoal, $30 \mathrm{~g} \mathrm{~L}^{-1}$ sucrose, and solidified with $2.5 \mathrm{~g} \mathrm{~L}^{-1}$ Phytagel. In a first experiment, the effect of continued subculture of explants every 30 days to fresh culture medium was determined. During a second experiment, part of the embryogenic calluses obtained were transferred to a liquid medium under agitation, consisting of MS with $5 \mu \mathrm{M}$ picloram or 2,4-dichlorophenoxyacetic acid (2,4-D). After 210 days, the calluses were transferred to semi-solid media for differentiating somatic embryos. It was observed that continued subculture of explants monthly was a determinant in stimulating and improving the formation of embryogenic calluses. Embryogenic calluses in liquid medium with 2,4-D significantly improved the percentage of differentiated somatic embryos (up to $80.2 \%$ ), with the largest amount of torpedo embryos ( 8.3 per callus). Regenerated plants with roots were individualised and transferred to a greenhouse, with close to $95 \%$ survival.
ARTICLE HISTORY

Accepted 24 July 2017

\section{KEYWORDS}

Arecaceae; callus culture; liquid media; somatic embryo differentiation; plant regeneration

\section{Introduction}

Oil palm (Elaeis guineensis Jacq.) is a perennial monocotyledon, monoecious, oleaginous, and of African origin. It is grown extensively in Asia, where currently the largest producers (Malaysia and Indonesia) are located, and in Africa and in Central and South America. In Brazil, commercial plantations are located chiefly in the northern and northeastern regions, mainly in the state of Pará, with close to $80 \%$ of commercial plantations (Chia, Lopes, Cunha, Rocha, \& Lopes, 2009).

Currently a major portion of commercial varieties planted are F1 hybrids of the tenera type, resulting from a cross of the Dura x Pisifera (D x P) types. Although they have a high oil yield, hybrids are subject to variations in productivity among plants of as much as 40\% (Low et al., 2008; Rajesh, Radha, Karun, \& Parthasarathy, 2003). Studies on the vegetative propagation by potentially high-production individuals could contribute to obtaining genotypes with higher oil productivity (Konan et al., 2010; Rajesh et al., 2003; Soh et al., 2011). Hence, tissue cultures are a promising alternative for this species' clonal propagation; once mastered, this may make clonal production possible for an increasing number of plants in a much reduced physical area (Soh et al.,
2011). Among the various tissue culture techniques, somatic embryogenesis is the most promising as it is a process by means of which haploid or somatic cells are developed through different embryogenic stages, giving rise to a complete plant without a fusion of gametes (Sharp, Sondahl, Caldas, \& Maraffa, 1980).

Despite this being a promising technique, the adoption of somatic embryogenesis for some species, such as the oil palm, is not yet entirely mastered. Therefore, its application is subject to limitations not only due the difficulties in controlling the stages of somatic embryogenesis, but also the constant handling of cultivations, such as during subcultures in initial cultivation periods, as well as laboratory costs such as specialised labour and gelling agents, which are reflected in the value of the plantlets produced. In fact, there is a consensus among researchers who work in cloning this species that the efforts developed to date with the use of semi-solid consistency media are technically unfeasible when considering large-scale cloning (Duval, Engelmann, \& Durand-Gasselin, 1995; ; Tarmizi \& Zaiton, 2007; Teixeira, Sondahl, Nakamura, \& Kirby, 1995).

The use of liquid-consistency media may be an alternative for cultivating oil palm in vitro. Among other advantages, as a rule liquid-consistency media 
provide better physical contact between explants and culture medium, which favours the assimilation rate of nutrients and water, compared to a semi-solid culture medium. Moreover, liquid media are easier to prepare and handle (Aberlenc-Bertossi, Noirot, \& Duval, 1999; Choi et al., 2008; Palanyandy et al., 2013; Scherwinski-Pereira et al., 2012; Tarmizi \& Zaiton, 2007).

In this work, we decided to use zygotic embryos as initial explants to adjust the protocol. Although a reproductive material, zygotic embryos are interesting to use because they can serve as model explants for analysis. Once the protocol has been adjusted for this type of explant, it is accepted that the results obtained can be used as standards for other types of explants, such as immature leaves, the explant routinely used for oil palm cloning (Konan et al., 2010). Currently, the protocol described here is being tested for cloning adult plants in our laboratory, with very promising results.

The objective of this study was to analyse the effect of subcultures during callus induction phase, and to assess the influence of submitting embryogenic calluses to liquid media on somatic embryogenesis and regeneration in oil palm.

\section{Material and methods}

The study employed as explants zygotic embryos obtained from ripe oil palm (Elaeis guineensis Jacq.) fruits, varieties C2501, C2528, and C7201. These varieties are all intraspecific varieties widely used for planting in Brazil. They were obtained from crosses between genitors Dura (Deli origin) x Pisifera (La Mé origin), realised and produced by the Oil Palm Genetic Improvement Program developed by Embrapa Western Amazon, Manaus, Amazonas, Brazil.

\section{Induction of somatic embryogenesis}

Induction of somatic embryogenesis was in accordance with the methodology prescribed by Balzon, Luis, and Scherwinski-Pereira (2013), with some modifications. Initially the seed endocarp was removed with the aid of a vice to extract the seeds. In the laboratory and under aseptic conditions the seeds were subjected to a disinfection procedure by immersion in alcohol $70 \%$ for 3 minutes in a laminar flow cabinet, followed by immersion in a $2.0-2.5 \%$ sodium hypochlorite solution (w/v) for 20 minutes. Subsequently the seeds were rinsed three times with sterile distilled water for residual removal of the disinfesting agents used.

Extracting zygotic embryos took place with the aid of tweezers and scalpel, and they were immediately inoculated on Petri dishes containing MS
(Murashige \& Skoog, 1962) medium complemented with $450 \mu \mathrm{M}$ picloram (4-amino-3,5,6-trichloropicolinic acid), $30 \mathrm{~g} \mathrm{~L}^{-1}$ sucrose, $0.5 \mathrm{~g} \mathrm{~L}^{-1}$ glutamine, $2.5 \mathrm{~g} \mathrm{~L}^{-1}$ activated charcoal and $2.5 \mathrm{~g} \mathrm{~L}^{-1}$ Phytagel (Sigma, St. Louis, MO). Once the embryos were inoculated, the Petri dishes were sealed with transparent plastic film and placed in the dark in the growth chamber, with temperature at $25 \pm 2{ }^{\circ} \mathrm{C}$ until the appearance of embryogenic calluses, characterised mainly by the formation of multigranular regions on the explants (Silva, Luis, and Scherwinski-Pereira (2012). The frequency of granular embryogenic callus formation was determined by counting the number of mature zygotic embryos forming callus out of the total number of embryos cultured on callus induction medium and multiplying the number by 100 .

\section{Influence of subcultures during the embryogenic callus induction phase}

During the callus induction period, in addition to a genotypical assessment in responses, whether or not to sub-cultivate explants in fresh culture media every 30 days was also assessed. The variables under analysis were the percentage of primary calluses and multigranular calluses with embryogenic structures formed after 5 months of cultivation.

The experimental procedure employed was entirely random with two treatments regarding the sub-cultivation type (whether or not to sub-cultivate explants every 30 days) and three oil palm varieties (C2501, C2528 and C7201). Explants were assessed and sub-cultivated for 5 months for callus formation. Each treatment was composed of 10 repetitions containing five zygotic embryos per plot.

\section{Submitting embryogenic calluses to liquid medium}

After the induction process, the multigranular regions of the calluses were separated by scraping with the aid of a spatula. Then, approximately $500 \mathrm{mg}$ of the calluses were transferred equally to two different liquid culture media: MS complemented with $5 \mu \mathrm{M}$ of Picloram and MS with $5 \mu \mathrm{M} 2,4-\mathrm{D}$. All the culture media were complemented with $30 \mathrm{~g} \mathrm{~L}^{-1}$ sucrose, $0.5 \mathrm{~g} \mathrm{~L}^{-1}$ glutamine and $0.2 \mathrm{~g} \mathrm{~L}^{-1}$ ascorbic acid.

The calluses were placed in $250 \mathrm{~mL}$ Erlenmeyer flasks containing $30 \mathrm{~mL}$ of liquid culture medium, and then subjected to agitation $(100 \mathrm{rpm})$ in a growth chamber at a temperature of $25 \pm 2{ }^{\circ} \mathrm{C}$. The culture media were renewed every 2 weeks over a 210 -day period. At this stage, the work consisted of at least five repetitions for each studied variety. 


\section{Differentiating cultivated and non-cultivated calluses in liquid medium}

It was then possible to separate two kinds of aggregates from the material inoculated in liquid medium: those that did not disaggregate completely and grew in the culture medium and those considered established, which were maintained in a liquid culture medium for multiplication. During this effort, priority was given to the use of larger aggregates, i.e. those that did not disaggregate and grew in a liquid culture medium under agitation. Hence, once isolated from the liquid medium the calluses were transferred to three different semi-solid culture media in order to assess the effect of submitting calluses to a liquid-consistency medium for differentiating somatic embryos, named M1: $1 / 2$ MS complemented with $30 \mathrm{~g} \mathrm{~L}^{-1}$ sucrose, $0.5 \mathrm{~g} \mathrm{~L} \mathrm{~L}^{-1}$ glutamine, $2.5 \mathrm{~g} \mathrm{~L}^{-1}$ activated charcoal; M2: MS complemented with $40 \mu \mathrm{M}$ picloram, $30 \mathrm{~g} \mathrm{~L}^{-1}$ sucrose, $0.5 \mathrm{~g} \mathrm{~L}^{-1}$ glutamine, $1.5 \mathrm{~g} \mathrm{~L}^{-1}$ activated charcoal; and M3: MS complemented with $12.3 \mu \mathrm{M}$ 2-isopentenyladenine (2iP), $0.6 \mu \mathrm{M}$ 1-naphthaleneacetic acid (NAA), $30 \mathrm{~g} \mathrm{~L}^{-1}$ sucrose, 0.5 g.L $\mathrm{L}^{-1}$ glutamine and $1.5 \mathrm{~g} \mathrm{~L}^{-1}$ activated charcoal. Those calluses not submitted to a liquid medium (control treatment) were transferred to M2 and M3 semisolid culture media, following the protocol by Silva et al. (2012).

The plant material was conditioned in a growth chamber at a temperature of $25 \pm 2^{\circ} \mathrm{C}$. Assessments were performed every 3 months of cultivation for as long as 12 months, and the variables examined were: percentage of aggregates with somatic embryos, number of embryos in the torpedo stage per aggregate, and regeneration rate. The regeneration rate was obtained by dividing the number of regenerated plants by the total number of somatic embryos per callus, and then multiplying this outcome by 100 . The experimental procedure employed in this experiment was entirely random. Each treatment was composed of 10 repetitions with at least three calluses per plot.

\section{Regenerating, rooting, and acclimatising plants}

The differentiated somatic embryos in the three tested culture media were transferred to the MS medium without growth regulators, with $30 \mathrm{~g} \mathrm{~L}^{-1}$ sucrose, $2.5 \mathrm{~g} \mathrm{~L}^{-1}$ activated charcoal and $2.5 \mathrm{~g} \mathrm{~L}^{-1}$ Phytagel for plant regeneration and development.

After their regeneration the plants originating from the somatic embryos of aggregates submitted to a liquid medium were separated and then transferred to test tubes $(25 \times 150 \mathrm{~mm})$ containing doublephase MS medium $(5 \mathrm{~mL}$ of liquid medium over $10 \mathrm{~mL}$ of semi-solid medium), complemented with
$57 \mu \mathrm{M}$ indole-3-butyric acid (IBA) and $30 \mathrm{~g} \mathrm{~L}^{-1}$ sucrose in order to improve root formation, following the methodology proposed by Gomes, Bartos, and Scherwinski-Pereira (2015).

The optimisation of rooting of plants was carried out in a growth chamber with a temperature of $25 \pm 2^{\circ} \mathrm{C}$, light period of 16 hours, and photosynthetic photon flux of $35-40 \mu \mathrm{mol} \mathrm{m}{ }^{-2} \mathrm{~s}^{-1}$, supplied by cold-white fluorescent lamps. Once the roots developed, the plants were removed from the test tubes and had their roots rinsed in running water in order to eliminate any excess culture medium. They were at this point planted in disposable cups (250 $\mathrm{mL}$ in capacity) filled with commercial substrate (Bioplant ${ }^{\oplus}$, Nova Ponte, Brazil) and rinsed sand $(3: 1 \mathrm{v} / \mathrm{v})$, and subsequently covered with a transparent plastic bag with small openings. The plants were placed under growth chamber conditions at $25^{\circ} \mathrm{C}$ for 2 weeks. Finally, the plants were kept under greenhouse conditions. When in the greenhouse, at every 30 days of cultivation and over a 90-day period, the percentage survival of plantlets was assessed.

\section{Statistical analysis}

The data obtained were submitted to variance analysis, and the averages were compared by the Tukey test at $5 \%$ probability and analysed using the Sanest statistical analysis program (Zonta \& Machado, 1984). Data expressed in percentage were transformed to arcsine $(\mathrm{x} / 100)^{\circ} .{ }^{5}$.

\section{Results and discussion}

\section{Induction of somatic embryogenesis}

Once the zygotic embryos were established in vitro (Figure 1(a)), primary callus formation began as of 30 days of cultivation in an induction medium, chiefly in the zygotic embryo's distal region, which is equal to the cotyledonary region (Figure 1(b)). After 60 days of cultivation all the treatments showed a primary callus formation (Figure 1(c)). During cultivation the calluses increased progressively in size (Figure $1(\mathrm{~d}-\mathrm{f})$ ) and after 150 days of cultivation in a somatic embryogenesis induction medium, significant differences were noted between culture conditions, assessed as to whether or not to sub-cultivate the explants every 30 days of cultivation. Table 1 reflects the influence of the induction medium's cultivation condition on the formation of primary and embryogenic calluses. In general, the condition of sub-cultivating every 30 days was instrumental in improving the embryogenic callus formation rate (20.8\%), with a nodular aspect and yellowish colour (Figure 1(e-f)). 

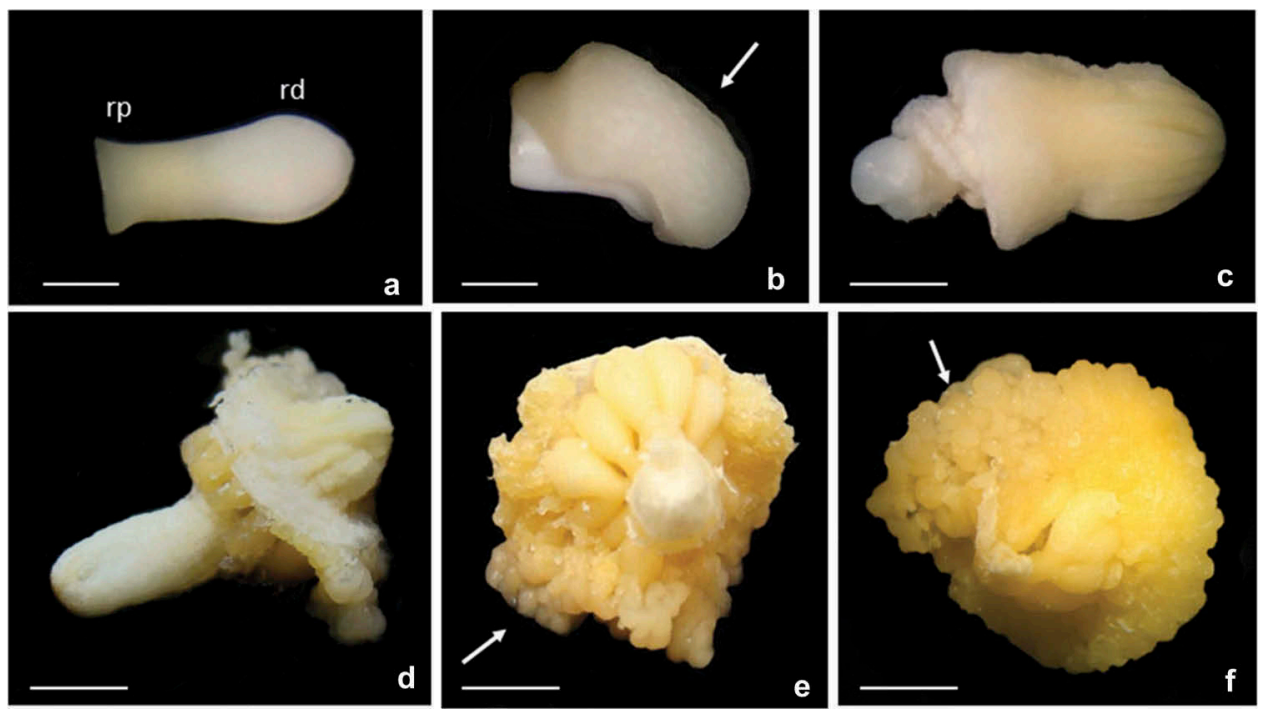

Figure 1. Aspect of somatic embryogenesis induction in oil palm based on zygotic embryos. (a) Zygotic embryo (proximal region - rp, distal region - rd). (b) Initial formation of primary callus, 30 days as of the distal region (arrow). (c) Primary callus at 60 days. (d) Primary callus at 90 days. (e) Callus with multigranular embryogenic structure at 120 days (arrow). (f) Callus with multigranular embryogenic structure at 150 days (arrow). Bars: $1 \mathrm{~mm}(\mathrm{a}, \mathrm{b}) ; 3 \mathrm{~mm}$ (c); $5 \mathrm{~mm}$ (d, e, f).

Table 1. Influence of the cultivation condition (whether or not to sub-cultivate explants every 30 days) on formation of primary and embryogenic calluses in oil palm zygotic embryos, varieties C2501, C2528 and C7201.

\begin{tabular}{|c|c|c|c|c|c|c|}
\hline \multirow[b]{2}{*}{ Variety } & \multicolumn{2}{|c|}{ Primary callus (\%) } & \multirow[b]{2}{*}{ Mean } & \multicolumn{2}{|c|}{$\begin{array}{l}\text { Embryogenic callus } \\
(\%)\end{array}$} & \multirow[b]{2}{*}{ Mean } \\
\hline & $\begin{array}{l}\text { Without } \\
\text { subculture }\end{array}$ & $\begin{array}{c}\text { With } \\
\text { subculture }\end{array}$ & & $\begin{array}{l}\text { Without } \\
\text { subculture }\end{array}$ & $\begin{array}{c}\text { With } \\
\text { subculture }\end{array}$ & \\
\hline C2501 & $66.4 \mathrm{aA}$ & $70.4 \mathrm{aA}$ & $68.4 \mathrm{a}$ & $1.7 \mathrm{aB}$ & $13.1 \mathrm{aA}$ & $7.4 \mathrm{a}$ \\
\hline C2528 & $67.3 \mathrm{aA}$ & $81.1 \mathrm{aA}$ & $74.2 \mathrm{a}$ & $0.4 \mathrm{aB}$ & $29.5 \mathrm{aA}$ & $14.9 \mathrm{a}$ \\
\hline C7201 & $80.9 \mathrm{aA}$ & $69.3 \mathrm{aA}$ & $75.1 \mathrm{a}$ & $0.4 \mathrm{aB}$ & $19.8 \mathrm{aA}$ & $10.1 \mathrm{a}$ \\
\hline Mean & $71.5 \mathrm{~A}$ & $73.6 \mathrm{~A}$ & & $0.8 \mathrm{~B}$ & $20.8 \mathrm{~A}$ & \\
\hline
\end{tabular}

Each value represents the mean of 10 replicates. Means followed by different letters, lower case in the columns and upper case in the lines, within each variable, differ by Tukey's test $(P \leq 0.05)$.

No significant differences were noted among the varieties under study (C2501, C2528 and C7201) for the primary callus formation, and on average the values observed for non-sub-cultivated and sub-cultivated explants every 30 days were $71.5 \%$ and $73.6 \%$, respectively. Nonetheless, when assessing embryogenic callus formation, significant differences were noted for treatment when explants were sub-cultivated every 30 days in a fresh culture medium. During this treatment and regardless of variety, values rose to as much as $29.5 \%$ of explants with embryogenic structure formation.

The results from this study agree with those obtained in a study with nine Brazilian oil palm varieties by Silva et al. (2012), who witnessed compact primary callus formation in zygotic embryos as of 60 days of cultivation. In addition, these authors rated the varieties in two groups according to the different responses regarding primary callus formation, which varied between $10 \%$ and $80 \%$, suggesting that differentiated responses may occur based on the genotype, where cultivation conditions are identical.

\section{Differentiating, regenerating, and acclimatising plants}

Table 2 reflects the influence of the liquid or semi-solid medium's consistency in differentiating somatic embryos. In general, submitting embryogenic calluses to a liquid culture medium in the presence of auxin 2,4$\mathrm{D}$ increased the percentage of calluses with differentiated somatic embryos. In the culture medium's average consistency, regardless of variety, roughly $52.4 \%$ of the calluses submitted to a liquid medium in the presence of 2.4-D showed differentiated somatic embryos, as against only $16.2 \%$ when the auxin employed in a liquid medium was picloram and $14.0 \%$ in control treatment, i.e. when the calluses were differentiated in a standard semi-solid medium (control).

Among the culture media tested (M1, M2, and M3), the M1 medium provided the best results in differentiating somatic embryos (58.2\%) when previously cultivated in $2,4-\mathrm{D}$. In an individual genotype analysis, it was noted that the C2528 in the M3 differentiating medium, having been submitted to the liquid medium with the addition of auxin 2,4-D, was the one that reflected the greatest callus rates with differentiated somatic embryos (80.2\%).

According to $\mathrm{Xu}$ and Bewley (1992), auxins are extremely important in inducing callogenesis and embryogenic cell formation, and once they are removed or reduced from the culture medium, they encourage embryogenic cells to form somatic 
Table 2. Influence of the medium's consistency (liquid or semi-solid) on the percentage of calluses with differentiated oil palm somatic embryos, varieties C2501, C2528 and C7201.

\begin{tabular}{|c|c|c|c|c|c|c|c|}
\hline \multirow[b]{2}{*}{ Medium consistency } & \multirow[b]{2}{*}{ Auxin } & \multirow[b]{2}{*}{ Differentiation medium } & \multicolumn{4}{|c|}{ Callus with somatic embryos (\%) } & \multirow[b]{2}{*}{ Mean Consistency } \\
\hline & & & C2501 & C2528 & C7201 & Mean treatment & \\
\hline \multirow{3}{*}{ Liquid } & & M1 & $32.1 \mathrm{ab}$ & $77.2 \mathrm{a}$ & $65.4 \mathrm{a}$ & $58.2 \mathrm{a}$ & \\
\hline & 2.4-D & M2 & $66.2 \mathrm{a}$ & $50.0 \mathrm{ab}$ & $41.5 \mathrm{ab}$ & $52.6 \mathrm{ab}$ & 52.4 \\
\hline & & M3 & $16.5 \mathrm{ab}$ & $80.2 \mathrm{a}$ & $42.2 \mathrm{ab}$ & $46.3 \mathrm{abc}$ & \\
\hline \multirow{4}{*}{ Liquid } & & M1 & $2.6 \mathrm{~b}$ & $20.6 a b$ & $34.5 a b$ & $19.2 \mathrm{bcd}$ & \\
\hline & Picloram & M2 & $1.0 \mathrm{~b}$ & $12.4 \mathrm{~b}$ & $35.2 \mathrm{ab}$ & $16.2 \mathrm{~cd}$ & 16.2 \\
\hline & & M3 & $0.0 \mathrm{~b}$ & $34.5 \mathrm{ab}$ & $5.4 \mathrm{~b}$ & $13.3 \mathrm{~d}$ & \\
\hline & & M1 & N.D. & N.D. & N.D. & N.D. & \\
\hline Semi-solid & & M2 & $6.7 \mathrm{~b}$ & $12.0 \mathrm{~b}$ & $10.9 \mathrm{ab}$ & $9.9 \mathrm{~d}$ & 14.0 \\
\hline (Control) & & M3 & $6.7 \mathrm{~b}$ & $12.9 \mathrm{~b}$ & $34.7 \mathrm{ab}$ & $18.1 \mathrm{bcd}$ & \\
\hline
\end{tabular}

Each value represents the mean of 10 replicates with at least three calluses per plot. Means followed by different letters in the columns are significantly different by Tukey's test $(P \leq 0.05)$.

Semi-solid media for somatic embryos differentiation: M1 - MS medium with half the concentration of its salts ( $1 / 2 \mathrm{MS})$, complemented with $30 \mathrm{~g} \mathrm{~L}^{-1}$

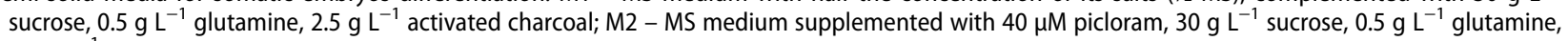
$1.5 \mathrm{~g} \mathrm{~L}^{-1}$ activated charcoal, and M3 - MS medium supplement with $12.3 \mu \mathrm{M}$ 2-isopentenyladenine (2iP), $0.6 \mu \mathrm{M}$ 1-naphthaleneacetic acid (NAA), $30 \mathrm{~g}$ $\mathrm{L}^{-1}$ sucrose, $0.5 \mathrm{~g} . \mathrm{L}^{-1}$ glutamine and $1.5 \mathrm{~g} \mathrm{~L}^{-1}$ activated charcoal; Semi-solid (control): embryogenic calluses that have not passed by liquid medium. N. D.: not determined.

embryos. This fact is in agreement with the outcome obtained in this study, as on average culture media without auxin, or with reduced concentrations, encouraged somatic embryo differentiation.

In this study, submitting embryogenic calluses to a liquid culture medium was more effective in the percentage of calluses with differentiated somatic embryos. Scherwinski-Pereira and Fortes (2003) and Scherwinski-Pereira et al. (2012) reported that in a liquid culture medium there is greater contact of explants with it, which is likely to provide an increase in the absorption of water and nutrients by explants, as compared with a medium of semi-solid consistency. Furthermore, liquid media also provide an improved dilution of exudates from the explants, thus preventing toxic compounds from accumulating on the explants being cultivated. However, in most cases it is required that media with this consistency should be subjected to some kind of agitation or aeration in order to obtain ideal conditions for providing oxygen to the explants (Choi et al., 2008; Levin, Alper, Stav, \& Watad, 1997; Tarmizi, Norjihan, \& Zaiton, 2004). In the case of date palms, Daguin and Letouze $(1988 ; 1998)$ found that submitting calluses to a liquid-consistency medium formed an important stage in the somatic embryo maturing process.

Table 3 reflects the effect of auxin and of the type of differentiating culture medium on the number of torpedo embryos formed by calluses and the regeneration rate of differentiated somatic embryos. In an individual analysis of varieties in differentiating culture media, it was found that in an M1 medium where the calluses were in a liquid medium with auxin 2,4-D, the C2528 variety showed the greatest number of somatic embryos (torpedo stage) per callus (8.3). On the other hand, significant statistical differences were not found in other varieties with regard to the number of differentiated somatic embryos (torpedo stage) in the several culture media tested, save for calluses from the C2501 variety cultivated in a liquid medium with picloram that in an M3 differentiating medium did not differentiate any somatic embryos. During a study that used differentiating culture media similar to those employed in this study, Silva et al. (2012) observed that oil palm varieties responded more efficiently regarding number of somatic embryos when the differentiating culture media were composed of low concentrations of growth regulators.

Table 3. Influence of auxin and of the type of differentiating culture medium on the number of torpedo embryos formed by calluses and the regeneration rate of differentiated somatic embryos, over a 12-month period.

\begin{tabular}{|c|c|c|c|c|c|c|c|c|c|c|c|}
\hline \multirow[b]{2}{*}{ Treatment/culture medium } & \multirow[b]{2}{*}{ Differentiation medium } & \multicolumn{4}{|c|}{$\begin{array}{l}\text { N. of torpedo somatic embryos/ } \\
\text { callus }\end{array}$} & \multirow[b]{2}{*}{ Mean auxin } & \multicolumn{4}{|c|}{ Regeneration frequency (\%) } & \multirow[b]{2}{*}{ Mean auxin } \\
\hline & & $\mathrm{C} 2501$ & C2528 & C7201 & Mean & & $\mathrm{C} 2501$ & $\mathrm{C} 2528$ & C7201 & Mean & \\
\hline \multirow{3}{*}{ Liquid + 2,4-D } & M1 & $2.6 \mathrm{a}$ & $8.3 \mathrm{a}$ & $1.2 \mathrm{a}$ & $4.0 \mathrm{a}$ & \multirow{3}{*}{2.9} & $8.9 \mathrm{a}$ & $29.5 \mathrm{ab}$ & $50.0 \mathrm{a}$ & $29.5 \mathrm{a}$ & \multirow{3}{*}{21.4} \\
\hline & M2 & $4.4 \mathrm{a}$ & $1.6 \mathrm{c}$ & $1.8 \mathrm{a}$ & $2.6 \mathrm{abc}$ & & $4.5 \mathrm{a}$ & $0.0 \mathrm{c}$ & $4.3 \mathrm{bc}$ & $2.9 \mathrm{~b}$ & \\
\hline & M3 & $2.5 \mathrm{a}$ & $2.6 \mathrm{bc}$ & $1.2 \mathrm{a}$ & $2.1 \mathrm{bc}$ & & $5.3 \mathrm{a}$ & $55.2 \mathrm{a}$ & $34.5 \mathrm{ab}$ & $31.7 \mathrm{a}$ & \\
\hline \multirow{3}{*}{ Liquid + Picloram } & M1 & $2.5 \mathrm{a}$ & $2.0 \mathrm{bc}$ & $2.4 \mathrm{a}$ & $2.3 \mathrm{abc}$ & \multirow{3}{*}{2.4} & $0.7 \mathrm{a}$ & $0.0 \mathrm{c}$ & $2.4 \mathrm{c}$ & $1.0 \mathrm{~b}$ & \multirow{3}{*}{2.2} \\
\hline & M2 & $2.7 \mathrm{a}$ & $3.7 \mathrm{~b}$ & $3.0 \mathrm{a}$ & $3.1 \mathrm{ab}$ & & $0.5 \mathrm{a}$ & $0.3 \mathrm{c}$ & $0.6 \mathrm{c}$ & $0.5 \mathrm{~b}$ & \\
\hline & M3 & $0.0 \mathrm{~b}$ & $2.5 \mathrm{bc}$ & $2.7 \mathrm{a}$ & $1.7 \mathrm{c}$ & & $0.0 \mathrm{a}$ & 11.5 bc & $3.4 b c$ & $5.0 \mathrm{~b}$ & \\
\hline
\end{tabular}

Each value represents the mean of 10 replicates with at least three calluses per plot. Means followed by different letters in the columns are significantly different by Tukey's test $(P \leq 0.05)$.

M1 - MS medium with half the concentration of its salts (1/2 MS), complemented with $30 \mathrm{~g} \mathrm{~L}^{-1}$ sucrose, $0.5 \mathrm{~g} \mathrm{~L}^{-1} \mathrm{glut}$ amine, $2.5 \mathrm{~g} \mathrm{~L}^{-1}$ activated charcoal; M2 - MS medium supplemented with $40 \mu \mathrm{M}$ picloram, $30 \mathrm{~g} \mathrm{~L}^{-1}$ sucrose, $0.5 \mathrm{~g} \mathrm{~L}^{-1}$ glutamine, $1.5 \mathrm{~g} \mathrm{~L}^{-1}$ activated charcoal, and M3 - MS medium supplement with $12.3 \mu \mathrm{M}$ 2-isopentenyladenine (2iP), $0.6 \mu \mathrm{M}$ 1-naphthaleneacetic acid (NAA), $30 \mathrm{~g} \mathrm{~L}^{-1}$ sucrose, $0.5 \mathrm{~g}^{-1} \mathrm{glutamine} \mathrm{and} 1.5 \mathrm{~g} \mathrm{~L}^{-1}$ activated charcoal. 
An important aspect to be stressed in this study is the asynchronous formation of somatic embryos, i.e. the formation of somatic embryos in various stages of development (globular and torpedo) and the incidence of secondary somatic embryogenesis (data not shown), whereby it was possible to demonstrate the formation of new somatic embryos based on already differentiated somatic embryos. These occurrences were also seen in other studies with palm trees (Balzon et al., 2013; Moura, Motoike, Ventrella, Sá Júnior, \& Carvalho, 2009; Scherwinski-Pereira, Guedes, Silva, Fermino Jr, \& Costa, 2010; Steinmacher, Cangahuala-Inocente, Clement, \& Guerra, 2007; Steinmacher, Guerra, Saare-Surminski, \& Lieberei, 2011).

This study provided differentiated answers on the somatic embryo regeneration rate in a medium without growth regulators. Somatic embryos that arose from the M1 and M3 differentiating media were those that showed the best regeneration rates $(29.5 \%$ and $31.7 \%$, respectively). Also, during somatic embryo regeneration, the speed of responses in this phase is heterogeneous, as some types of embryos are quicker than others in creating their first leaves and developing into complete plants. This fact may be very possibly related to the lack of synchrony with types of differentiated somatic embryos, as previously mentioned and already observed in other studies on oil palm (Balzon et al., 2013; Konan et al., 2010).

Somatic embryos germinated in plants with a vigorous development of the aerial part, although most of them were lacking roots (Figure 2(e and f)). And as described by Gomes et al. (2015), a complementary stage was also required in this study in order to optimise root formation in regenerated plants for submission to acclimatisation (Figure $2(\mathrm{~g}$ and $\mathrm{h})$ ). Once they were rooted, acclimatised plants showed a $95.2 \%$ survival rate at the end of 90 days (Figure $2(\mathrm{i}-\mathrm{k})$ ).

In conclusion, the condition of sub-cultivated explants formed by zygotic embryos every 30 days in a fresh culture medium is instrumental in improving the rate of embryogenic callus formation in oil palm. Submission of these embryogenic calluses to a liquid culture medium in the presence of auxin 2,4-D encourages differentiation of somatic embryos. After submitting calluses to a liquid culture medium, culture media in the somatic embryo differentiating stage should have low concentrations or no growth regulator, as these conditions have resulted in the
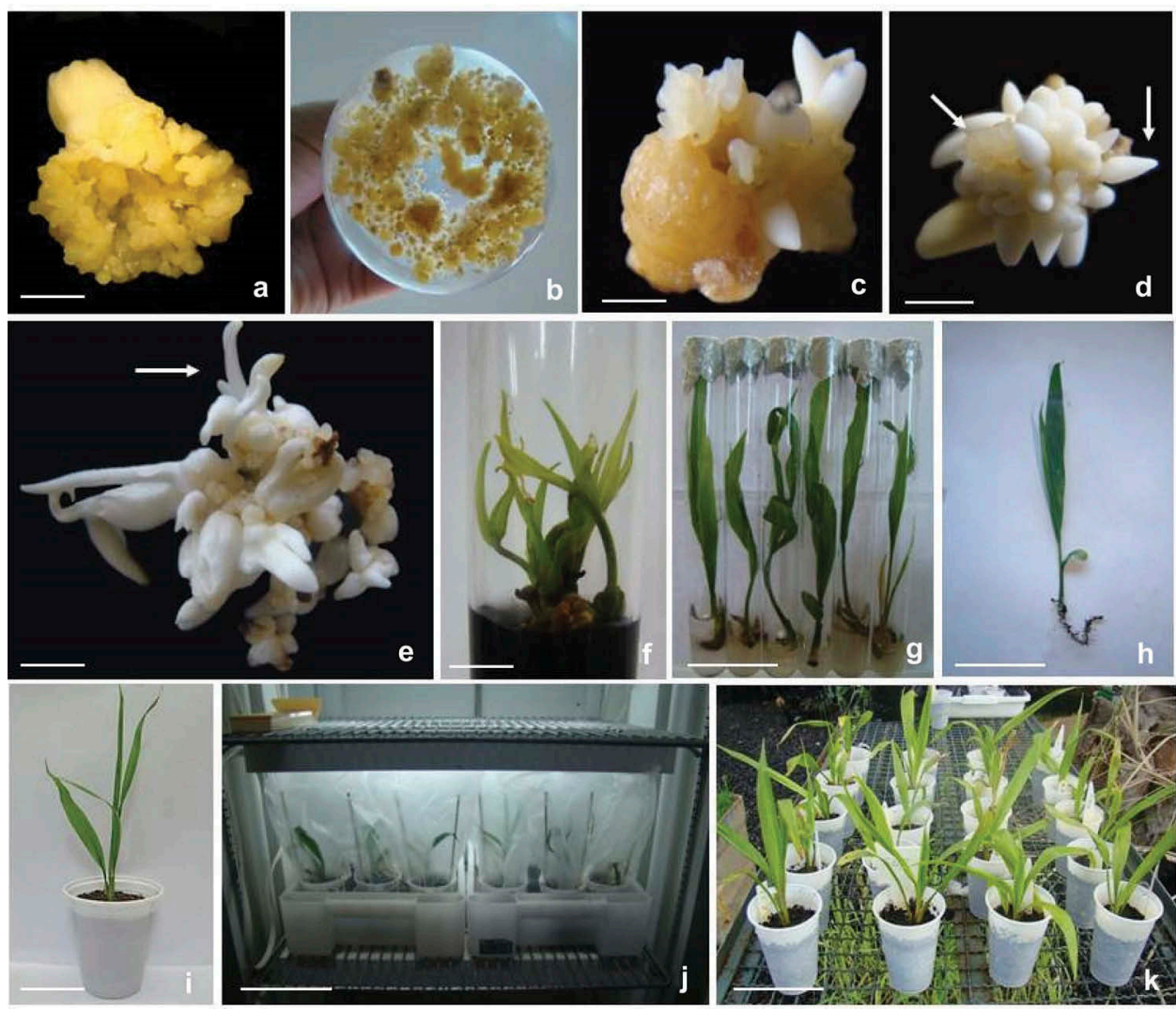

Figure 2. Submission of embryogenic calluses to liquid culture medium: differentiating, regenerating and acclimatising plants. (a) Embryogenic callus. (b) Aspects of liquid medium cultivations. (c) Formation of differentiated somatic embryos. (d) Somatic embryos in globular and torpedo stages (arrows). (e) Somatic embryos in regeneration (arrow). (f) Regenerated plant. (g) Regenerated plants without roots. (h) Regenerated plant with roots. (i) Regenerated plant in disposable cup, filled with substrate. (j) Regenerated plants in growth chamber. (k) Plantlets in greenhouse. Bars: $5 \mathrm{~mm}(\mathrm{a}, \mathrm{c}, \mathrm{d}, \mathrm{e}) ; 10 \mathrm{~mm}(\mathrm{f}) ; 5 \mathrm{~cm}$ $(g, h, i, j, k)$. 
best oil palm regeneration rates. The present study describes a consistent methodology for improving somatic embryogenesis in oil palm through continuous sub-cultivations, as well as passage of embryogenic calluses by liquid medium. Studies are now in progress in order to establish synchronised embryogenic microcalluses from different commercial varieties, including interspecific hybrids from immature leaves from adult plants as initial explant.

\section{Acknowledgements}

The authors thank Financiadora de Estudos e Projetos (Finep Grant 01.08.0597.01), Coordenação de Aperfeiçoamento de Pessoal de Nível Superior (Capes/Embrapa 001-2011/Grant 39), and Conselho Nacional de Desenvolvimento Científico e Tecnológico (CNPq Grant 426637/2016-0) for financial support and fellowships. We also wish to extend our thanks to Dr. Ricardo Lopes and Dr. Raimundo Nonato (Brazilian Oil Palm Breeding Program), Embrapa Amazonia Ocidental, Manaus, AM, Brazil, for providing the biological material for experiments.

\section{Disclosure statement}

No potential conflict of interest was reported by the authors.

\section{Funding}

This work was supported by the Conselho Nacional de Desenvolvimento Científico e Tecnológico [426637/20160];Coordenação de Aperfeiçoamento de Pessoal de Nível Superior [001-2011/Grant 39]; Financiadora de Estudos e Projetos [01.08.0597.01];

\section{ORCID}

J. E Scherwinski-Pereira (i) http://orcid.org/0000-0001$6271-332 X$

\section{References}

Aberlenc-Bertossi, F., Noirot, M., \& Duval, Y. (1999). BA enhances the germination of oil palm somatic embryos derived from embryogenic suspension cultures. Plant Cell, Tissue and Organ Culture, 56, 53-57. doi:10.1023/ A:1006241215717

Balzon, T.A., Luis, Z.G., \& Scherwinski-Pereira, J.E. (2013). New approaches to improve the efficiency of somatic embryogenesis in oil palm (Elaeis guineensis Jacq.) from mature zygotic embryos. In Vitro Cellular \& Developmental Biology - Plant, 49, 41-50. doi:10.1007/ s11627-012-9479-3

Chia, G.S., Lopes, R., Cunha, R.N.V., Rocha, R.N.C., \& Lopes, M.T.G. (2009). Repetibilidade da produção de cachos de híbridos interespecíficos entre caiaué e dendezeiro. Acta Amaz, 39, 249-254. doi:10.1590/S004459672009000200001

Choi, D., Andrade, M.H.C., Willis, L.B., Cho, C., Schoenheit, J., Boccazzi, P., ... Rha, C. (2008). Effect of agitation and aeration on yield optimization of oil palm suspension culture. Journal of Oil and Palm Researcher, $1,23-34$.

Daguin, F., \& Letouze, R. (1988). Regeneration of date palm (Phoenix dactylifera) by somatic embryogenesis: Improved efficiency by shaking in liquid medium. Fruits 43, 191-194.

Daguin, F., \& Letouze, R. (1998). Régénération du palmier dattier (Phoenix dactylifera L.) par embryogenèse somatique: Amelioration de l'efficacité par passage en milieu liquide agite. Fruits, 43, 191-194.

Duval, Y., Engelmann, F., \& Durand-Gasselin, T. (1995). Somatic embryogenesis in oil palm (Elaeis guineensis jacq.). In Y. P. S. Bajaj (Ed.), Biotechnology in agriculture and forestry, somatic embryogenesis and synthetic seed I (pp. 335-352). Berlin, Heidelberg: Springer-Verlag.

Gomes, H.T., Bartos, P.M.C., \& Scherwinski-Pereira, J.E. (2015). Optimizing rooting and survival of oil palm (Elaeis guineensis) plantlets derived from somatic embryos. In Vitro Cellular \& Developmental Biology Plant, 51, 111-117. doi:10.1007/s11627-015-9669-x

Konan, K.E., Durand-Gasselin, T., Kouadio, Y.J., Flori, A., Rival, A., Duval, Y., \& Pannetier, C. (2010). In vitro conservation of oil palm somatic embryos for 20 years on a hormone-free culture medium: Characteristics of the embryogenic cultures, derived plantlets and adult palms. Plant Cell Reports, 29, 1-13. doi:10.1007/s00299009-0787-y

Levin, R., Alper, Y., Stav, R., \& Watad, A. (1997). Methods and apparatus for liquid media and semiautomated micropropagation. Acta Horticulturae, 447, 659-664. doi:10.17660/ActaHortic.1997.447.129

Low, E.L., Alias, H., Boon, S., Shariff, E.M., Tan, C.A., Ooi, L.C.L., ... Singh, R. (2008). Oil palm (Elaeis guineensis Jacq.) tissue culture ESTs: Identifying genes associated with callogenesis and embryogenesis. BMC Plant Biology, 8, 1-19. doi:10.1186/1471-2229-8-62

Moura, E.F., Motoike, S.Y., Ventrella, M.C., Sá Júnior, A. Q., \& Carvalho, M.C. (2009). Somatic embryogenesis in macaw palm (Acrocomia aculeata) from zygotic embryos. Scientia Horticulturae, 119, 447-454. doi:10.1016/j.scienta.2008.08.033

Murashige, T., \& Skoog, F. (1962). A revised medium for rapid growth and bioassays with tobacco tissue cultures. Physiologia Plantarum, 15, 473-497. doi:10.1111/ ppl.1962.15.issue-3

Palanyandy, S.R., Suranthran, P., Gantait, S., Sinniah, U.R., Subramaniam, S., Aziz, M.A., ... Roowi, S.H. (2013). In vitro developmental study of oil palm (Elaeis guineensis Jacq.) polyembryoids from cell suspension using scanning electron microscopy. Acta Physiol Plant, 35, 17271733. doi:10.1007/s11738-012-1201-x

Rajesh, M.K., Radha, E., Karun, A., \& Parthasarathy, V.A. (2003). Plant regeneration from embryo-derived callus of oil palm - the effect of exogenous polyamines. Plant Cell, Tissue and Organ Culture, 75, 41-47. doi:10.1023/ A:1024679910085

Scherwinski-Pereira, J.E., Araruna, E.C., Silva, T.L., Mesquita, A.G.G., Maciel, A.S., \& Costa, F.H.S. (2012). Double-phase culture system for large scale production of pineapple. Plant Cell, Tissue and Organ Culture (PCTOC), 109, 263-269. doi:10.1007/s11240-011-0091-8

Scherwinski-Pereira, J.E., \& Fortes, G.R.L. (2003). Protocolo para produção de material propagativo de batata em meio líquido. Pesquisa Agropecuária Brasileira, 38, 1035-1043. doi:10.1590/S0100-204X2003000900003

Scherwinski-Pereira, J.E., Guedes, R.S., Silva, T.L., Fermino Jr., P.C.P., \& Costa, F.H.S. (2010). Somatic 
embryogenesis and plant regeneration in oil palm using thin cell layer technique. In Vitro Cellular \& Developmental Biology - Plant, 46, 378-385. doi:10.1007/s11627-010-9279-6

Sharp, W.R., Sondahl, M., Caldas, L.S., \& Maraffa, S.B. (1980). The physiology on in vitro assexual embryogenesis. Horticult Review, 2, 268-310.

Silva, R.C., Luis, Z.G., \& Scherwinski-Pereira, J.E. (2012). Differential responses to somatic embryogenesis of different genotypes of Brazilian oil palm (Elaeis guineensis Jacq.). Plant Cell, Tissue and Organ Culture (PCTOC), 111, 59-67. doi:10.1007/s11240-012-0170-5

Soh, A.C., Wong, G., Tan, C.C., Chew, P.S., Chong, S.P., Ho, Y.W., ... Kumar, K. (2011). Commercial-scale propagation and planting of elite oil palm clones: Research and development towards realization. Journal of Oil and Palm Researcher, 23, 935-952.

Steinmacher, D.A., Cangahuala-Inocente, G.C., Clement, C.R., \& Guerra, M.P. (2007). Somatic embryogenesis from peach palm zygotic embryos. In Vitro Cellular \& Developmental Biology - Plant, 43, 124-132. doi:10.1007/ s11627-007-9032-y

Steinmacher, D.A., Guerra, M.P., Saare-Surminski, K., \& Lieberei, R.A. (2011). A temporary immersion system improves in vitro regeneration of peach palm through secondary somatic embryogenesis. Annals of Botany, 108, 1463-1475. doi:10.1093/aob/mcr033

Tarmizi, A.H., Norjihan, M.A., \& Zaiton, R. (2004). Multiplication of oil palm suspension cultures in a bench-top (2-litre) bioreactor. Journal of Oil and Palm Researcher, 16, 44-49.

Tarmizi, A.H., \& Zaiton, R. (2007). Development of the MPOB fast transfer technique (MoFaTT) system for maintenance and maturation of oil palm culture aggregates. Journal of Oil and Palm Researcher, 19, 435-439.

Teixeira, J.B., Sondahl, M.R., Nakamura, T., \& Kirby, E.G. (1995). Establishment of oil palm cell suspensions and plant regeneration. Plant Cell, Tissue and Organ Culture, 40, 105-111. doi:10.1007/BF00037662

Xu, N., \& Bewley, J.D. (1992). Contracting pattern of somatic and zygotic embryo development in alfafa (Medicago sutiva L.) as revealed by scaning eletron microscopy. Plant Cell Reports, 11, 279-284.

Zonta, E.P., \& Machado, A.A. (1984). SANEST - Sistema de Análise Estatística para Microcomputadores. Registrado na Secretaria Especial de Informática sob nº 066060 categoria A. Universidade Federal de Pelotas, Pelotas, RS, Brazil 